\title{
Characterization of subpopulation lacking both B-cell and plasma cell markers in Waldenstrom macroglobulinemia cell line
}

\author{
Naoki Wada, Maosheng Zhan, Yumiko Hori, Keiichiro Honma, Jun-ichiro Ikeda and Eiichi Morii
}

Cancer cells with tumorigenic potential are limited to a small population known as cancer-initiating cells (CICs). To date, $\mathrm{CICs}$ have not been identified in non-Hodgkin's lymphomas. Here, we investigated a candidate of CICs of an indolent nonHodgkin's lymphoma, Waldenstrom macroglobulinemia (WM), using WM cell line MWCL-1. WM tumor expresses both B-cell and plasma cell markers, CD20 and CD138. When stained with anti-CD20 and anti-CD138 antibodies, MWCL-1 cells were classified into three subpopulations: $\mathrm{CD}_{2} 0^{-} \mathrm{CD} 138^{-}, \mathrm{CD}_{2} 0^{+} \mathrm{CD}_{138^{-}}$, and $\mathrm{CD} 20^{+} \mathrm{CD} 138^{+}$. When cultured, $\mathrm{CD}_{20} \mathrm{CD}^{-} \mathrm{C}^{-}$cells yielded all three subpopulations, but $\mathrm{CD} 20^{+}$cells did not yield $\mathrm{CD} 20^{-} \mathrm{CD} 138^{-}$cells. Higher reactive oxygen species (ROS) expelling and in vitro colony formation activities were detected in $\mathrm{CD}_{20}^{-} \mathrm{CD}^{-} 38^{-}$cells than in $\mathrm{CD}_{20}{ }^{+} \mathrm{CD}_{138^{-}}$and $\mathrm{CD} 20^{+} \mathrm{CD}_{138^{+}}$cells. When cultured in the absence of serum or with anti-cancer drug, $\mathrm{CD}_{20}{ }^{-} \mathrm{CD} 138^{-}$cells were resistant to apoptosis. In contrast, $\mathrm{CD} 20^{+} \mathrm{CD} 138^{+}$cells were vulnerable to apoptosis in the same condition. In fact, the immunohistochemical analysis with clinical samples revealed that tumor cells in apoptosis were CD138-positive. The production of all three subpopulations, the efficient ROS expelling and in vitro colony-forming activities, and the resistance to apoptosis suggested that the $\mathrm{CD} 20^{-} \mathrm{CD} 138^{-}$cell might be a candidate of $\mathrm{CICs}$ in WM. Laboratory Investigation (2014) 94, 79-88; doi:10.1038/labinvest.2013.129; published online 4 November 2013

KEYWORDS: cancer-initiating cells; CD138; CD20; lymphoplasmacytic lymphoma; Waldenstrom macroglobulinemia

Tumors derive from a single clone, but consist of heterogenous cell populations whose features and functions are diverse. Recently, it has been demonstrated that tumorigenic potential is limited to a small population known as cancerinitiating cells (CICs). ${ }^{1-10}$ CICs yield both CICs and nonCICs, whereas non-CICs rarely yield CICs. ${ }^{1,2,9,10}$ Relatively high number of colonies is yielded from CICs in vitro, as compared with non-CICs. ${ }^{9-11}$ CICs are one of the causes of tumor recurrence, because CICs efficiently escape apoptosis by effluxing antitumor drugs and degrading reactive oxygen species (ROS) that are related to radiation-induced apoptosis., ${ }^{9} 10,12$ For the complete cure of tumors, it is essential to eliminate CICs. However, the knowledge of CICs is limited in most tumors. Especially, CICs of indolent lymphoma have not been reported. This might be due to the relatively homogenous surface markers in lymphoma cells and the low rate of proliferation that make the assay of tumorigenic potential difficult.
Waldenstrom macroglobulinemia (WM) is an indolent non-Hodgkin's lymphoma that is classified into lymphoplasmacytic lymphoma (LPL), and overproduces monoclonal immunoglobulin M protein (IgM). ${ }^{13,14}$ In contrast to most indolent lymphoma, WM consists of tumors with relatively diverse surface markers. WM shows a spectrum of small B lymphocytes, plasma cells, and lymphoplasmacytoid cells. ${ }^{14,15}$ In addition to the expression of soluble IgM and the pan B-cell antigens such as CD20, WM tumor cells coexpress the markers of mature plasma cells such as CD138. ${ }^{14,16,17}$ Recently, WM cell line, called MWCL-1, has been established. MWCL-1 has a rigorous clonal relationship to the primary WM tumor, which retains similar immunophenotypic and biologic properties of the initial tumor clone. ${ }^{18}$ Because of the heterogenous phenotypes of lymphoma cells and the establishment of cell line, WM is suitable for the study of CICs in lymphoma as compared with other types of indolent lymphoma. In the present study,

Department of Pathology, Osaka University Graduate School of Medicine, Suita, Osaka, Japan

Correspondence: Dr E Morii, Department of Pathology (C3), Osaka University Graduate School of Medicine, 2-2 Yamadaoka, Suita, Osaka 565-0871, Japan.

E-mail: morii@molpath.med.osaka-u.ac.jp

Received 14 August 2013; revised 1 October 2013; accepted 6 October 2013 
using MWCL-1 cell line, we found that the population lacking both B-lymphocyte and plasma cell markers was the candidate of CICs of WM.

\section{MATERIALS AND METHODS Cell Line and Sorting}

WM cell line, MWCL-1 was provided from Mayo Foundation for Medical Education and Research. MWCL-1 cells were cultured in IMDM + GlutaMAX ${ }^{\mathrm{TM}}$-I (Gibco by Life Technologies, Carlsbad, USA) supplemented with $10 \%$ fetal calf serum (FCS, HyClone Laboratories, Logan, USA). Cells were stained with CD20-Allophycocyanin (APC) (clone 2H7, BD Biosciences, San Jose, USA) and CD138-Phycoerythrin (PE) (clone MI15, BD Biosciences) antibodies, and $\mathrm{CD}^{-} 0^{-}$ $\mathrm{CD} 138^{-}, \mathrm{CD}_{2}{ }^{+} \mathrm{CD} 138^{-}, \mathrm{CD} 20^{+} \mathrm{CD} 138^{+}$populations were sorted with FACS Aria II (BD Biosciences). When stained with CD20 and CD138, we removed the dead cells with propidium iodide and reacted cells in the presence of human FcR blocking reagent (Miltenyi Biotec, Auburn, USA). The proportion of dead cells was marginal (0.8\%), and the dot blot pattern obtained with FcR blocking was comparable to the pattern without blocking (Supplementary Figures $1 \mathrm{~A}$ and $1 \mathrm{~B}$ ). Then, in the following experiments using CD20 and CD138 antibodies, cells were stained without FcR blocking. In some experiments, cells were stained with CD20APC, and sorted into $\mathrm{CD} 20^{-}$and $\mathrm{CD} 20^{+}$cells. As negative controls, cells were left unstained under identical conditions. Isolated cells were cultured, and their immunophenotypes were examined with FACS Canto II (BD Biosciences). Data were analyzed by Cell Quest software (BD Biosciences).

\section{Assay for Intracellular ROS Level}

Cells were incubated with $10 \mu \mathrm{M}$ of 5-(and-6)-chloromethyl$2^{\prime}, 7^{\prime}$-dichlorodihydrofluorescein diacetate, acetyl ester (CM$\mathrm{H}_{2}$ DCFDA, Invitrogen by Life Technologies, Carlsbad, USA) and hydrogen peroxide at $37^{\circ} \mathrm{C}$ for $20 \mathrm{~min}$. Then, CM$\mathrm{H}_{2}$ DCFDA-expressing conditions were detected with FACS Canto II.

\section{Immunocytochemistry}

FoxO3a expression was immunocytochemically examined in MWCL-1 cells. Cells were cytospun, fixed with $10 \%$ formalin. After treatment with peroxidase blocking solution (DAKO, Glostrup, Denmark), cells were incubated with anti-FoxO3a antibody (Abcam, Cambridge, UK, dilution at 1:250). Then, cells were treated with ChemMate EnVision kit (DAKO). $\mathrm{DAB}$ (DAKO) was used as a chromogen.

\section{In Vitro Colony Formation Assay}

A total of $5 \times 10^{4}$ and $1 \times 10^{5}$ suspended cells were plated in culture dishes with $1-2 \mathrm{ml}$ methylcellulose-containing Dulbecco's Modified Eagle's Medium supplemented with $15 \%$ FCS. The number of colonies was counted on day 35 and 23 , respectively.

\section{Detection of Apoptotic and Senescent Cells}

MWCL-1 cells were cultured with or without FCS for $6 \mathrm{~h}$. In a separate experiment, MWCL-1 cells were cultured with $100 \mu \mathrm{g} / \mathrm{ml}$ cis-diammine-dichloroplatinum (II) (CDDP, cisplatin) for $36 \mathrm{~h}$. Apoptotic cells were detected with APOPCYTO Annexin V-Azami-Green Apoptosis Detection Kit (MBL, Nagoya, Japan) according to the manufacturer's instructions. Increase of senescence-associated expression of $\beta$-galactosidase (SA- $\beta$-Gal) activity is a known characteristic of senescent cells. The proportion of SA- $\beta$-Gal positive cells was counted using the senescence detection kit (BioVision, Milpitas, USA).

\section{Immunohistochemistry}

Cleaved-caspase 3 expression was immunohistochemically examined in clinical cases of LPL diagnosed in Osaka University Hospital from 2002 to 2013. Histological specimen was fixed in $10 \%$ formalin and routinely processed for paraffin-embedding. Paraffin-embedded samples were stored in a dark room of Department of Pathology, Osaka University at room temperature. Sections were cut at $4 \mu \mathrm{m}$ thickness. After antigen retrieval with Pascal pressurized heating chamber (DAKO), immunohistochemistry was performed using an automated staining system (Dako Autostainer, DAKO). Antibodies used for immunohistochemistry were CD20, CD3, CD138 (DAKO, dilution at 1:400, 1:50, 1:50, respectively), and cleaved-caspase 3 (Cell Signaling Technology, Danvers, USA, dilution at 1:150). Double staining of CD138 and cleaved-caspase 3 was performed using EnVision ${ }^{\mathrm{TM}} \mathrm{G} / 2$ Doublestain System, Rabbit/Mouse (DAB + /Permanent Red) (DAKO). CD138 was stained with brown color and cleavedcaspase 3 with red color. Double staining of CD20 and CD138 was also carried out, in which CD20 was stained in brown and CD138 in red. The study was approved by the institutional review board for clinical research at Osaka University Hospital (No. 12461).

\section{Statistical Analysis}

Statistical analyses were performed using $t$-tests. The values are shown as the mean \pm standard error (s.e.) of at least three experiments. The $P$-values of less than 0.05 were considered to be statistically significant.

\section{RESULTS \\ Immunophenotypic Transition of MWCL-1 Subpopulation}

As in the case of WM, MWCL-1 is consisted of subpopulations with distinct immunophenotype, such as $\mathrm{CD} 20^{+}$or $\mathrm{CD}_{20}{ }^{-}$and $\mathrm{CD}_{138^{+}}$or $\mathrm{CD} 138^{-} .18$ First, immunophenotypic transition of $\mathrm{CD}_{2} 0^{+}$and $\mathrm{CD}_{2} 0^{-}$cells was examined. Sorted $\mathrm{CD}_{20}{ }^{-}$cells yielded $\mathrm{CD} 20^{+}$subpopulation at $36 \mathrm{~h}$ after the initiation of culture (Figure 1a). The proportion of $\mathrm{CD} 20^{+}$cells gradually increased, and the CD20 expression profile was similar to the original at $132 \mathrm{~h}$ after the initiation of 
a

$0 \mathrm{hr}$

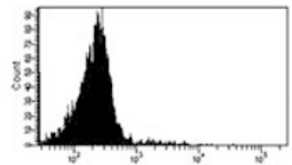

$12 \mathrm{hr}$

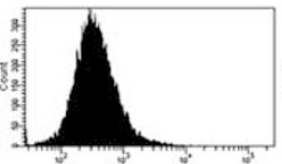

$36 \mathrm{hr}$

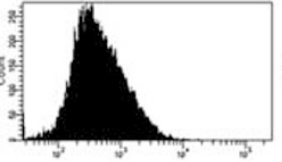

$84 \mathrm{hr}$

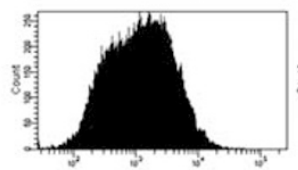

$132 \mathrm{hr}$

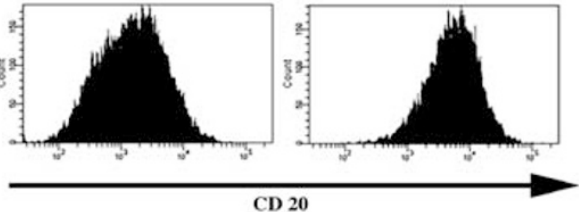

C

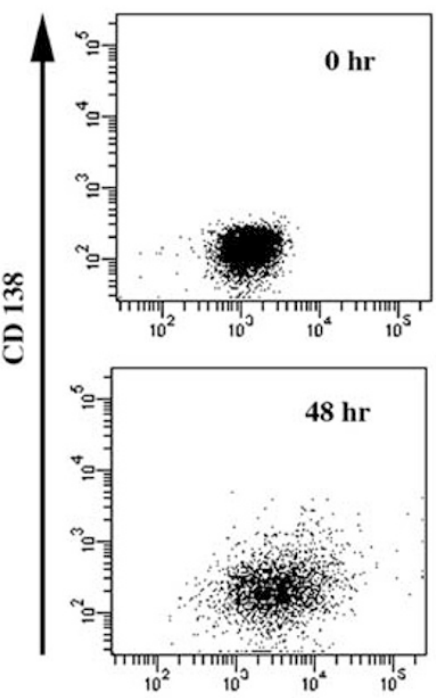

CD20
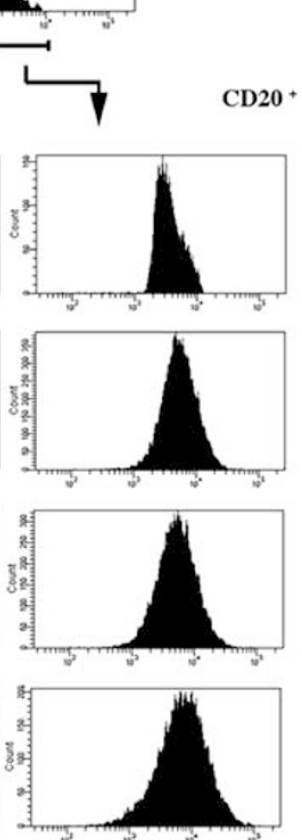

CD 20 b

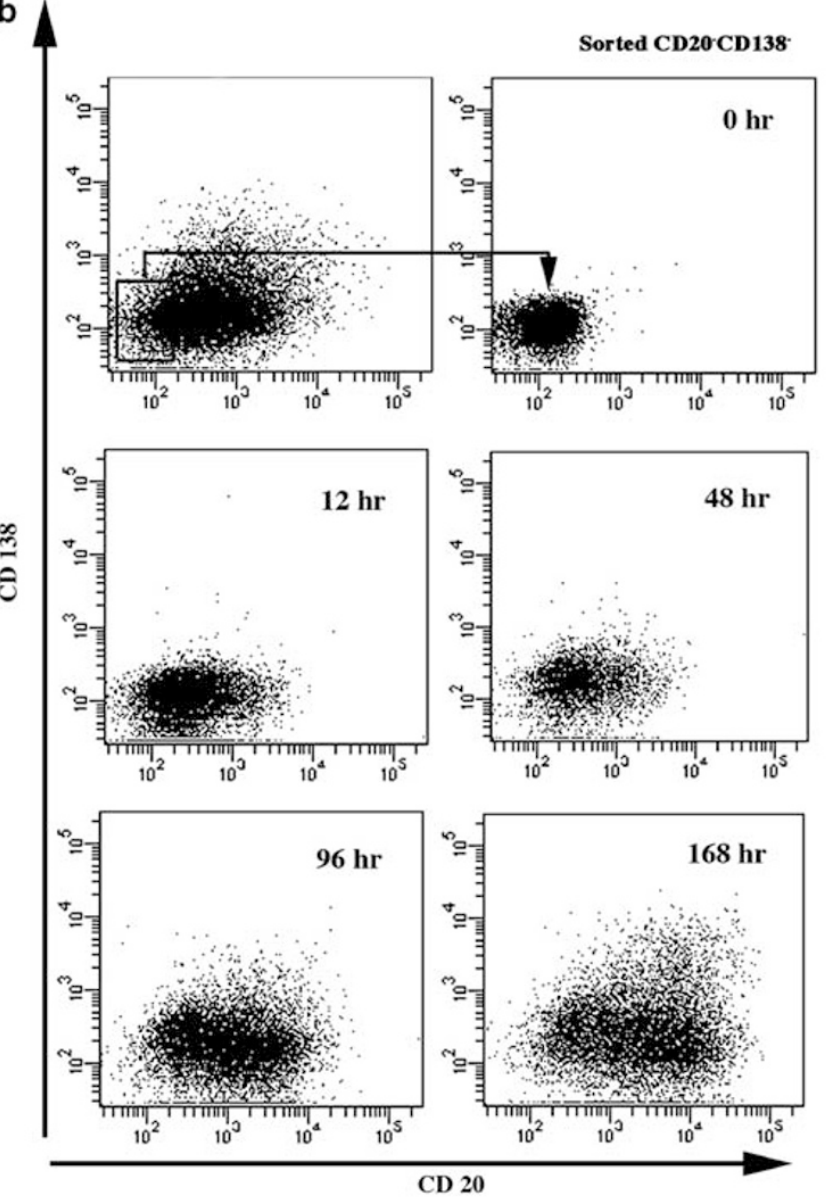

Sorted $\mathrm{CD}^{+} \mathrm{CDD}^{+} \mathrm{Cs}^{+}$
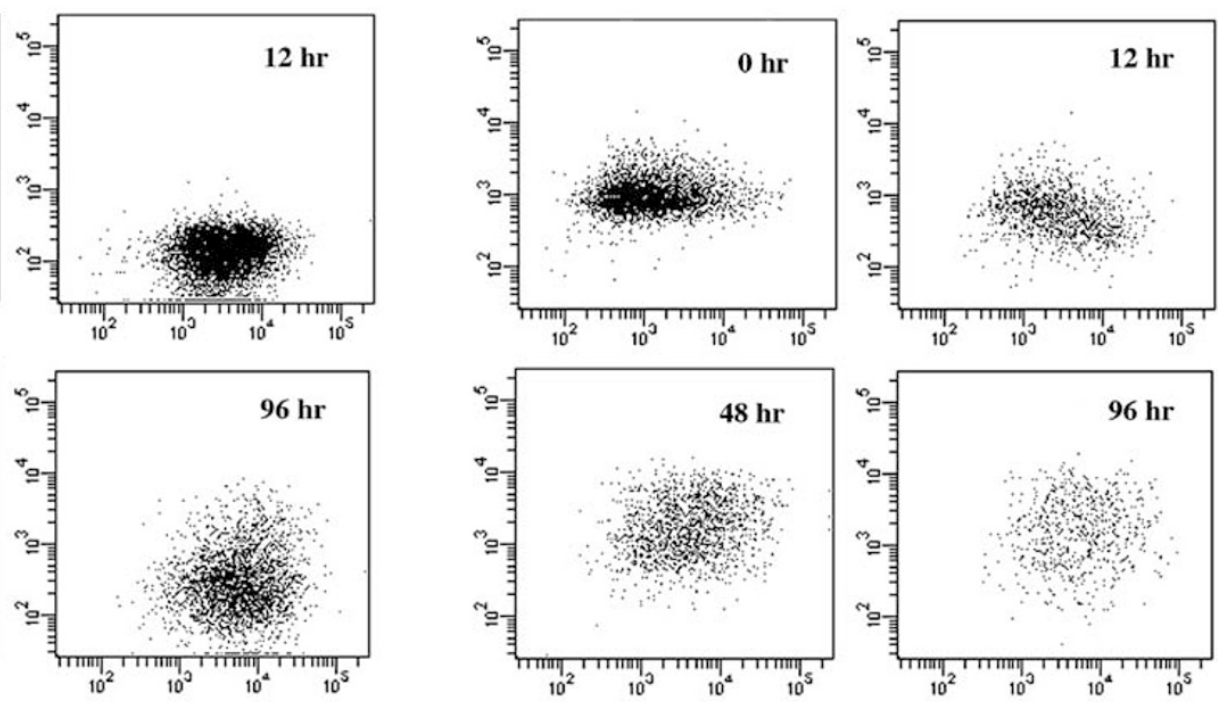

CD 20

Figure 1 Immunophenotypic transition during the culture of sorted subpopulations. (a) MWCL-1 cells were stained with CD20. The sorted CD20 ${ }^{+}$and $\mathrm{CD}^{-} 0^{-}$cells were independently cultured, and the change of CD20 expression was examined for $132 \mathrm{~h}$. (b) MWCL-1 cells were stained both CD20 and CD138. Most MWCL-1 cells were classified into three subpopulations: $\mathrm{CD}_{2} 0^{-} \mathrm{CD} 138^{-}, \mathrm{CD}_{2} 0^{+} \mathrm{CD} 138^{-}$, and $\mathrm{CD} 20^{+} \mathrm{CD}_{138^{+}}$. The sorted $\mathrm{CD} 20^{-}$ CD138 ${ }^{-}$cells were cultured, and the change of CD20 and CD138 expression was examined. (c) The sorted CD20 ${ }^{+} \mathrm{CD}_{138^{-}}$and $^{\mathrm{CD} 20^{+}} \mathrm{CD} 138^{+}$cells were cultured, and CD20 and CD138 expression levels were examined. 
culture (Figure 1a). In contrast, sorted $\mathrm{CD} 20^{+}$cells did not yield any $\mathrm{CD} 20^{-}$subpopulation.

Next, MWCL-1 was simultaneously stained with both antiCD20 and anti-CD138 antibodies. We detected four populations $\left(\mathrm{CD} 20^{-} \mathrm{CD}_{138^{-}}, \mathrm{CD} 20^{+} \mathrm{CD} 138^{-}, \mathrm{CD} 20^{-}\right.$ $\mathrm{CD}_{138}{ }^{+}$and $\mathrm{CD} 20^{+} \mathrm{CD} 138^{+}$), and the proportion of each populations was $14.4 \pm 1.6, \quad 72.6 \pm 2.2, \quad 1.4 \pm 0.6$, and $11.7 \pm 2.4$, respectively (Figure $1 \mathrm{~b}$ ). This proportion was similar to that observed in clinical samples of LPL (10.9 \pm 1.2 , $82.3 \pm 0.9, \quad 0.1 \pm 0.1, \quad$ and $\quad 6.8 \pm 0.4, \quad$ respectively, Supplementary Figure 2). As the number of $\mathrm{CD}_{2}{ }^{-}$ $\mathrm{CD} 38^{+}$cells was extremely low (Figure $1 \mathrm{~b}$ ), the remaining three subpopulations $\left(\mathrm{CD} 20^{-} \mathrm{CD} 138^{-}, \mathrm{CD} 20^{+} \mathrm{CD} 138^{-}\right.$, and $\mathrm{CD} 20^{+} \mathrm{CD} 138^{+}$) were sorted. When cultured for $168 \mathrm{~h}$, cells derived from $\mathrm{CD} 20^{-} \mathrm{CD} 138^{-}$subpopulation showed similar immunophenotype to the original MWCL-1 (Figure 1b). The sorted $\mathrm{CD}^{+} 0^{+} \mathrm{CD}_{138^{-}}$cells yielded $\mathrm{CD} 20^{+} \mathrm{CD} 138^{+}$but not $\mathrm{CD} 20^{-} \mathrm{CD} 138^{-}$subpopulation (Figure 1c). The sorted $\mathrm{CD} 20^{+} \mathrm{CD} 138^{+}$cells also yielded $\mathrm{CD} 20^{+} \mathrm{CD}_{138^{-}}$subpopulation, but no $\mathrm{CD} 20^{-} \mathrm{CD} 138^{-}$ subpopulation was detected (Figure 1c). These results indicated that $\mathrm{CD} 20^{-} \mathrm{CD} 138^{-}$subpopulation could yield all three subpopulations. Once CD20 was expressed, cells did not transit to the CD20-negative state. In contrast, CD138 expression level appeared to be interchangeable; $\mathrm{CD} 20^{+}$ $\mathrm{CD} 138^{-}$cells transited to $\mathrm{CD} 20^{+} \mathrm{CD} 138^{+}$and vice versa.

In addition to the bulk culture, a single cell culture of $\mathrm{CD}_{20}{ }^{-} \mathrm{CD} 138^{-}$subpopulation was done. As in the case of bulk culture, cells derived from a single sorted CD20 $\mathrm{CD} 138^{-}$cell showed similar immunophenotype to the original MWCL-1 (Supplementary Figure 3).

\section{High ROS-Expelling Activity in CD20- ${ }^{-} \mathrm{CD} 138^{-}$ Subpopulation}

Cells were stimulated with hydrogen peroxide, and then ROS concentration was evaluated by staining with $\mathrm{CM}-\mathrm{H}_{2} \mathrm{DCFDA}$ after incubation for $20 \mathrm{~min}$. During the incubation, cells with high ROS expelling activity become $\mathrm{CM}-\mathrm{H}_{2}$ DCFDA-negative. Approximately half of $\mathrm{CD}_{2} 0^{-}$cells became CM- $\mathrm{H}_{2}$ DCFDAnegative, whereas the proportion of $\mathrm{CM}-\mathrm{H}_{2} \mathrm{DCFDA}$-negative cells was lower in $\mathrm{CD} 20^{+}$than $\mathrm{CD} 20^{-}$cells $(44.5 \pm 0.1 \%$ in $\mathrm{CD} 20^{-}$vs $33.6 \pm 0.3 \%$ in $\mathrm{CD}_{20} 0^{+}$, Figure 2a). As most $\mathrm{CD} 20^{-}$cells showed immunophenotype of $\mathrm{CD} 20^{-}$ $\mathrm{CD}_{138^{-}}^{-}$(Figure 1b), these results suggested that ROSexpelling activity of $\mathrm{CD} 20^{-} \mathrm{CD} 138^{-}$cells was higher than $\mathrm{CD} 20^{+}$cells.

\section{Distinct FoxO3a-Expression Pattern Between CD20 and $\mathrm{CD}_{2}{ }^{+}$Subpopulations}

It has been reported that ROS-expelling activity is correlated to the nuclear localization of the master transcription factor FoxO3a. ${ }^{19-21}$ When the sorted $\mathrm{CD}^{-} 0^{-}$and $\mathrm{CD} 20^{+}$ subpopulations was immunocytochemically stained with anti-FoxO3a, the localization of FoxO3a was different: FoxO3a was mostly localized in the nuclei of $\mathrm{CD} 20^{-}$cells and was diffusely present in the cytoplasm of $\mathrm{CD} 20^{+}$cells (Figure 2b).

\section{ROS Expelling Activity and FoxO3a Expression in the Sorted Cells}

We examined the ROS expelling activity and FoxO3a expression in the sorted $\mathrm{CD} 20^{-} \mathrm{CD} 138^{-}, \mathrm{CD} 20^{+} \mathrm{CD} 138^{-}$, and $\mathrm{CD} 20^{+} \mathrm{CD} 138^{+}$subpopulations. As expected in the above-mentioned experiments, ROS expelling activity was the highest in $\mathrm{CD}_{20}^{-} \mathrm{CD}^{-} 38^{-}$subpopulation (Figure 2c). FoxO3a was localized in the nuclei in $\mathrm{CD} 20^{-} \mathrm{CD} 138^{-}$cells, but in the cytoplasm of $\mathrm{CD} 20^{+} \mathrm{CD} 138^{-}$and $\mathrm{CD} 20^{+}$ $\mathrm{CD} 138^{+}$cells (Figure 2c).

\section{High In Vitro Colony Formation Activity in CD20 CD138- Subpopulation}

The $\mathrm{CD}_{20}^{-} \mathrm{CD}_{138^{-}}, \mathrm{CD} 20^{+} \mathrm{CD} 138^{-}$, and $\mathrm{CD} 20^{+}$ $\mathrm{CD}_{138^{+}}$subpopulations were plated in methylcellulosecontaining medium, and the number of colonies was counted. When a total of $5 \times 10^{4}$ cells were plated, colonies were obtained from $\mathrm{CD} 20^{-} \mathrm{CD} 138^{-}$subpopulation but not from $\mathrm{CD}_{20}{ }^{+} \mathrm{CD}_{138^{-}}$and $\mathrm{CD} 20^{+} \mathrm{CD} 138^{+}$subpopulations (Figure 3). When a total of $1 \times 10^{5}$ cells were plated, the number of colonies derived from $\mathrm{CD}_{2} 0^{-} \mathrm{CD} 138^{-}$subpopulation was significantly higher than that of $\mathrm{CD} 20^{+}$ $\mathrm{CD}_{138^{+}}$and $\mathrm{CD} 20^{+} \mathrm{CD}_{138^{-}}$subpopulations (Figure 3).

\section{Resistance to Apoptosis}

After serum depletion, the apoptotic cells were examined in $\mathrm{CD} 20^{-} \mathrm{CD} 138^{-}, \mathrm{CD} 20^{+} \mathrm{CD} 138^{-}$, and $\mathrm{CD} 20^{+} \mathrm{CD} 138^{+}$ subpopulations. Even in the presence of serum, 20\% of $\mathrm{CD} 20^{+} \mathrm{CD}_{138}{ }^{+}$cells were dead (Figure $4 \mathrm{a}$ ). Serum depletion did not affect the proportion of apoptotic cells in $\mathrm{CD} 20^{-} \mathrm{CD} 138^{-}$subpopulation. In contrast, the proportion of apoptotic cells increased slightly in $\mathrm{CD} 20^{+} \mathrm{CD} 138^{-}$ subpopulation and significantly in $\mathrm{CD} 20^{+} \mathrm{CD} 138^{+}$subpopulation (Figures $4 \mathrm{~b}$ and $\mathrm{c}$ ).

Next, apoptosis was induced by the addition of anti-cancer drug, CDDP. When CDDP was added, the proportion of apoptotic cells was not changed in $\mathrm{CD} 20^{-} \mathrm{CD} 138^{-}$subpopulation. In contrast, apoptotic cells increased moderately in $\mathrm{CD} 20^{+} \mathrm{CD} 138^{-}$and significantly in $\mathrm{CD} 20^{+} \mathrm{CD} 138^{+}$ subpopulations (Figures $5 \mathrm{a}$ and $\mathrm{b}$ ). These results indicated that the rank order of resistance to apoptosis was as follows: $\mathrm{CD}_{20}{ }^{-} \mathrm{CD}_{138}{ }^{-}>\mathrm{CD} 20^{+} \mathrm{CD} 138^{-}>\mathrm{CD} 20^{+} \mathrm{CD} 138^{+}$.

\section{Cellular Senescence in $\mathrm{CD}_{2}{ }^{+} \mathrm{CD}_{138^{+}}$Subpopulation}

Cellular senescence was examined with $\mathrm{SA}-\beta-\mathrm{Gal}$ staining. MWCL-1 cells were sorted into $\mathrm{CD} 20^{-} \mathrm{CD} 138^{-}, \mathrm{CD} 20^{+}$ $\mathrm{CD} 138^{-}$, and $\mathrm{CD} 20^{+} \mathrm{CD} 138^{+}$subpopulations, and stained with SA- $\beta$-Gal. Most cells in $\mathrm{CD} 20^{-} \mathrm{CD} 138^{-}$and $\mathrm{CD} 20^{+}$ $\mathrm{CD} 138^{-}$subpopulations were negative for $\mathrm{SA}-\beta$-Gal. In contrast, approximately half of $\mathrm{CD} 20^{+} \mathrm{CD} 138^{+}$cells were SA- $\beta$-Gal-positive (Figures $6 \mathrm{a}$ and $\mathrm{b}$ ). 
a
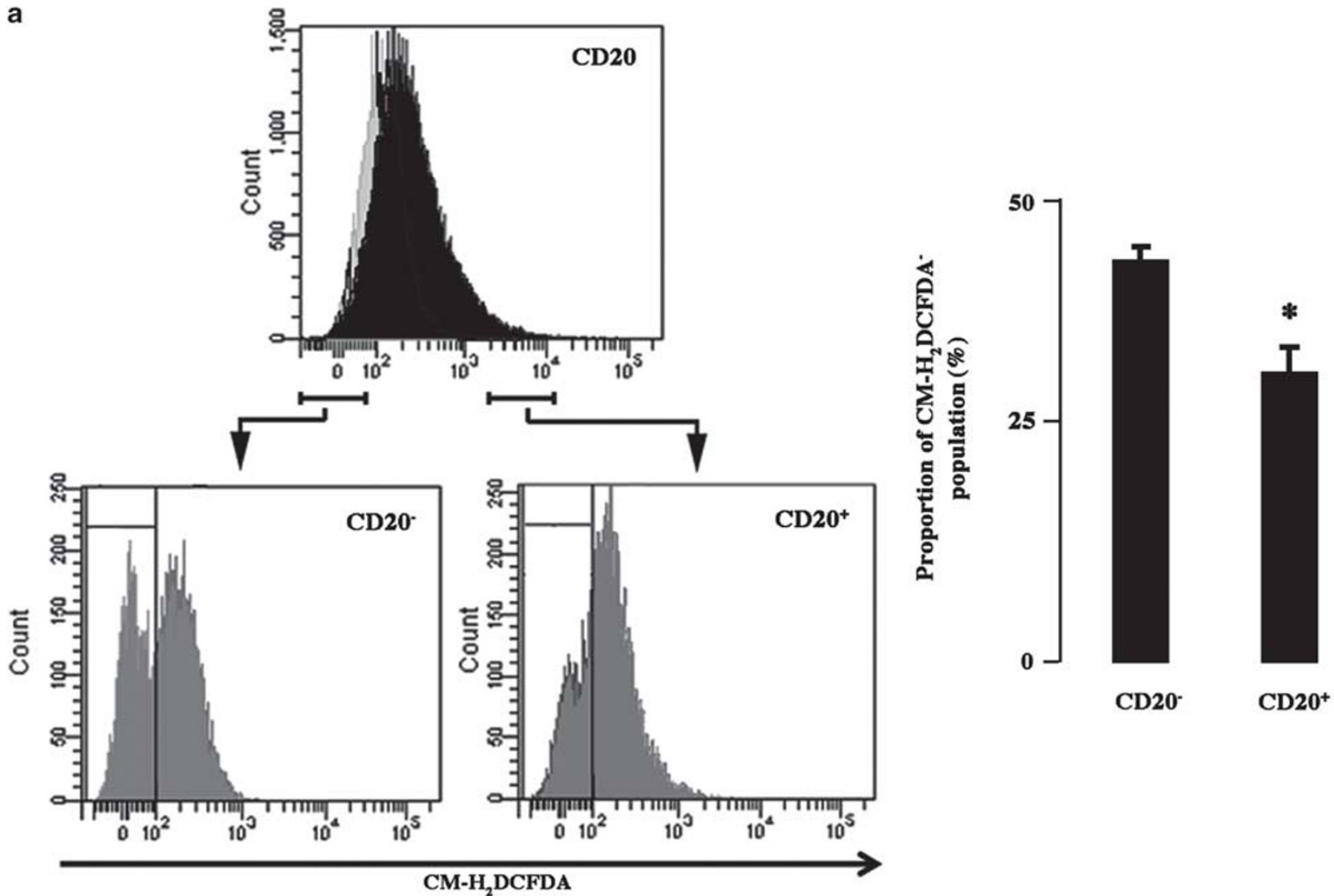

b CD20.

$\mathrm{CD20}^{+}$

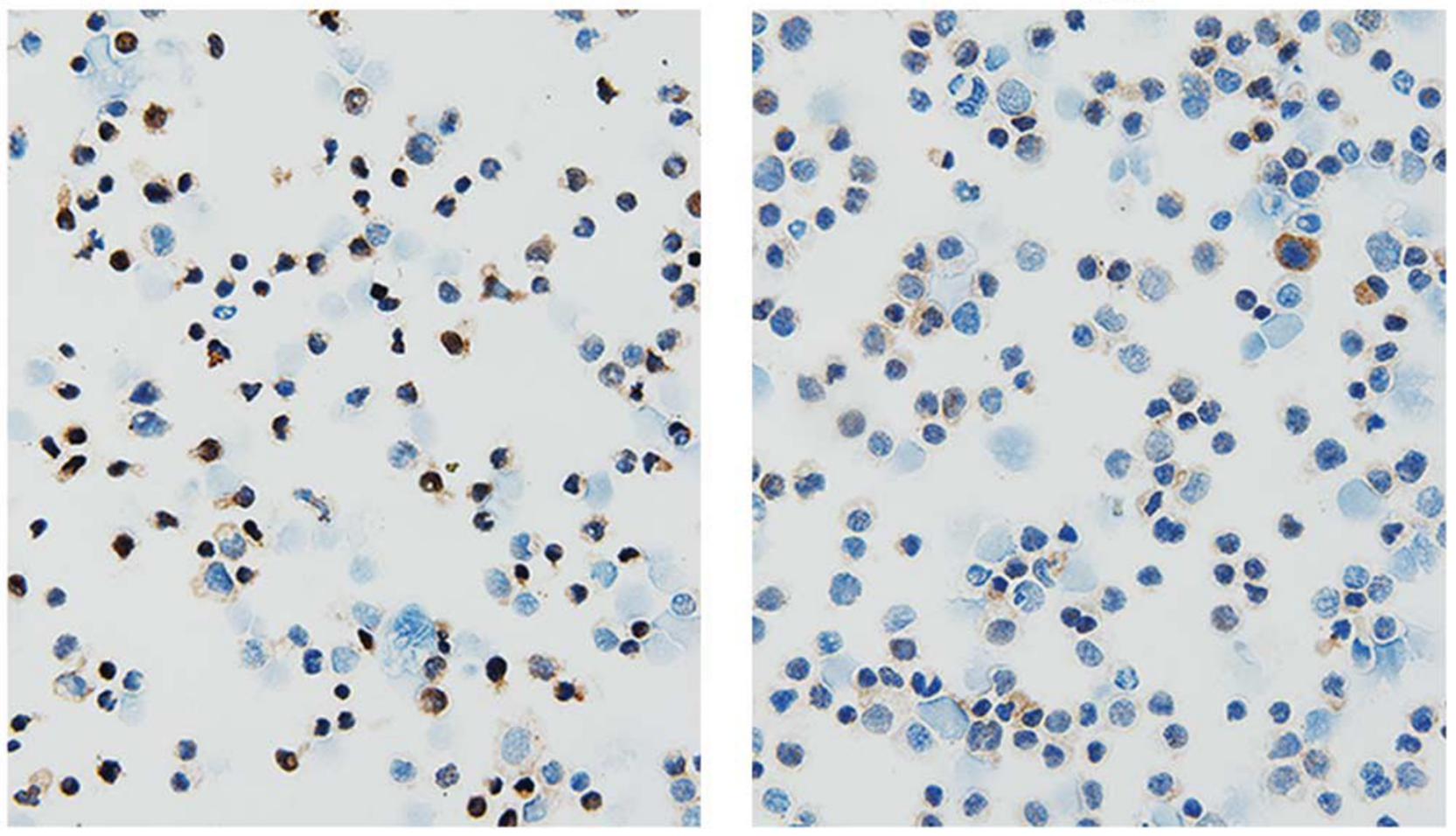

Figure 2 For caption see next page. 

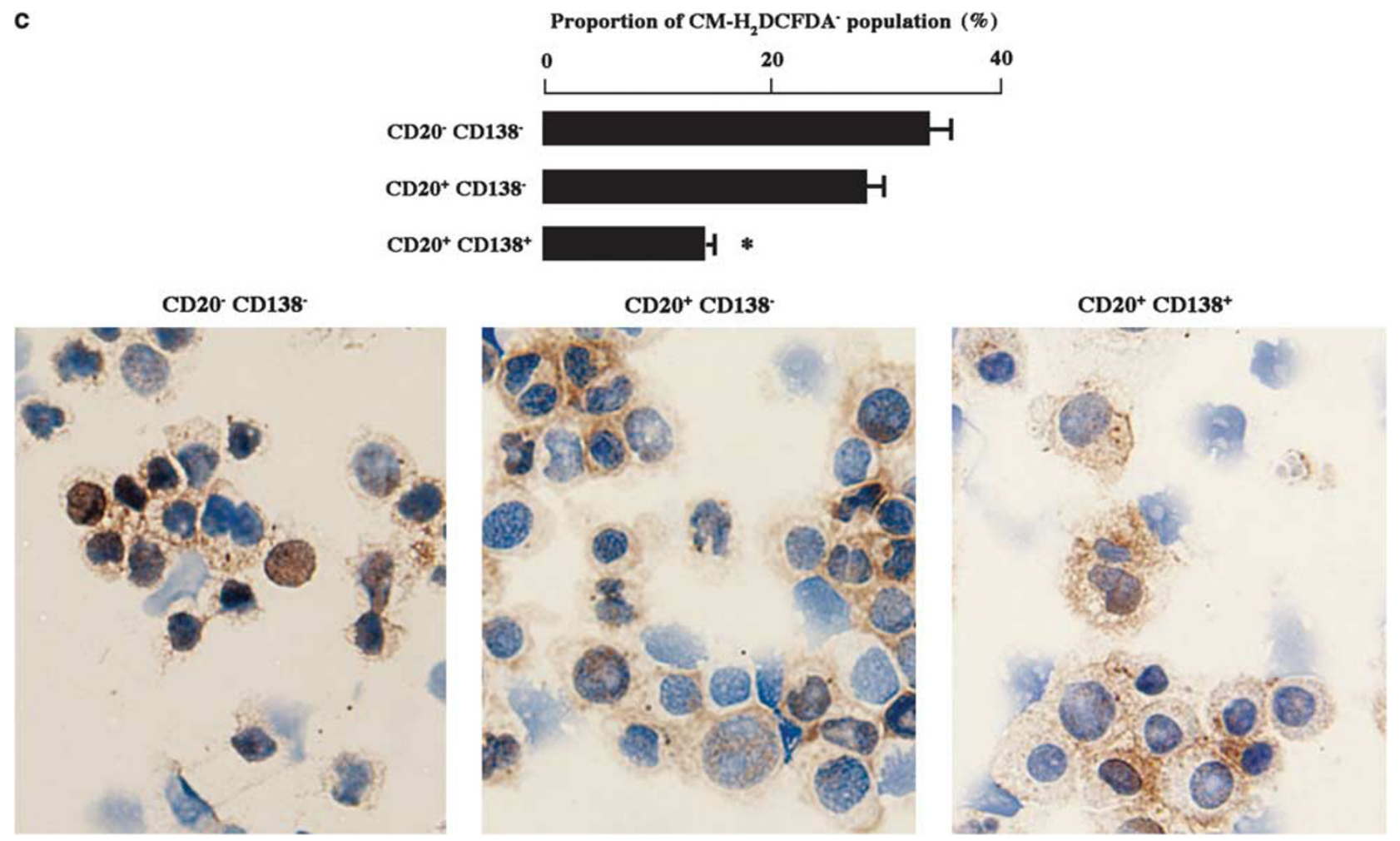

Figure 2 ROS expelling activity in $\mathrm{CD}_{2} 0^{-}$and $\mathrm{CD}_{2} 0^{+}$cells. (a) MWCL-1 cells were stained with $\mathrm{CD} 20$ (the gray area was correspond to negative control), and cultured with $100 \mathrm{mM}$ of hydrogen peroxide and $10 \mu \mathrm{M}$ of $\mathrm{CM}_{-} \mathrm{H}_{2} \mathrm{DCFDA}$, a marker of ROS. At 20 min after the initiation of culture, the proportion of cells that became $\mathrm{CM}-\mathrm{H}_{2}$ DCFDA-negative was higher in $\mathrm{CD}_{2} 0^{-}$than in $\mathrm{CD}_{2} 0^{+}$cells. Proportion of $\mathrm{CM}-\mathrm{H}_{2}$ DCFDA-negative cells was shown by bars. ${ }^{*} P<0.05$ when compared with $\mathrm{CD} 20^{+}$cells. (b) Immunocytochemistry of $\mathrm{CD}_{2} 0^{-}$and $\mathrm{CD}_{2} 0^{+}$cells expressing FoxO3a. The proportion of FoxO3a-positive cells was higher in $\mathrm{CD}_{20}^{-}$than in $\mathrm{CD}_{2} 0^{+}$cells. FoxO3a was mostly localized in the nuclei of $\mathrm{CD} 20^{-}$cells, but diffusely present in

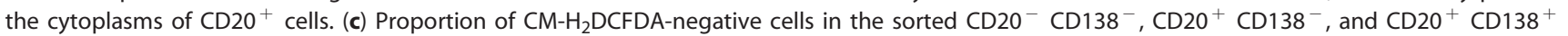
cells treated with $50 \mathrm{mM}$ of hydrogen peroxide. ${ }^{*} P<0.05$ when compared with $\mathrm{CD} 20^{+} \mathrm{CD} 138^{+}$cells. Immunocytochemistry revealed that FoxO3a was mostly localized in the nuclei of $\mathrm{CD}_{20}{ }^{-} \mathrm{CD} 138^{-}$cells but in the cytoplasm of $\mathrm{CD}_{20}{ }^{+} \mathrm{CD}_{138^{-}}$and $\mathrm{CD} 20^{+} \mathrm{CD}_{138^{+}}$cells.

\section{$\mathrm{CD}^{+}{ }^{+} \mathrm{CD}_{138}{ }^{+}$Subpopulation in Clinical Samples of \\ LPL}

Finally, clinical samples of LPL were examined in the view of CD20 and CD138 expression. When stained with CD20 antibody, few $\mathrm{CD} 20^{-}$cells were detected, indicating that the number of $\mathrm{CD}^{-} 0^{-}$subpopulation was limited in clinical samples of LPL (Figure 7a). Then, lymphoma cells with CD138 expression were considered to be mostly CD20 ${ }^{+}$ $\mathrm{CD}_{138^{+}}$subpopulation in clinical samples. Apoptotic cells are known to be cleaved-caspase 3-positive. Double staining of cleaved-caspase 3 and $\mathrm{CD} 138$ revealed that most $\mathrm{CD} 138^{+}$ cells were stained with cleaved-caspase 3 (Figure $7 \mathrm{~b}$ ). This suggested that the proportion of cells in apoptosis was higher in $\mathrm{CD} 20^{+} \mathrm{CD}_{138^{+}}$subpopulation than in $\mathrm{CD} 20^{+}$ $\mathrm{CD} 138^{-}$subpopulation, which was consistent with the result obtained in MWCL-1.

\section{DISCUSSION}

Few studies have been done on CICs of malignant lymphomas. In Hodgkin lymphoma, we have recently reported that a portion of small cells with a single nucleus resembling Hodgkin cells was a candidate of CICs, where high in vitro

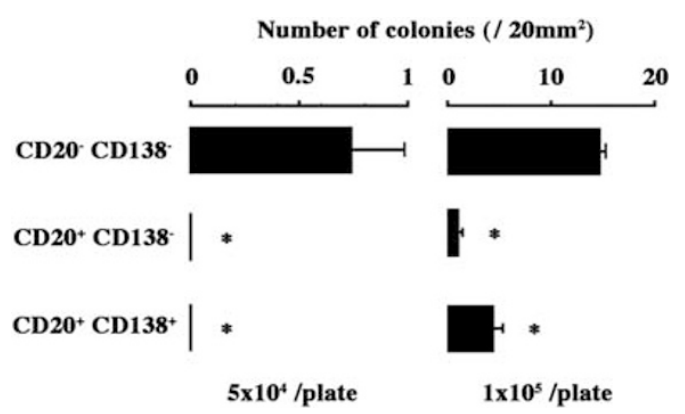

Figure 3 In vitro colony formation. When a total of $5 \times 10^{4}$ cells were plated in methylcellulose-containing medium, colonies were obtained from $\mathrm{CD} 20^{-} \mathrm{CD}_{138^{-}}$subpopulation but not from $\mathrm{CD} 20^{+} \mathrm{CD} 138^{-}$and $\mathrm{CD}^{2} 0^{+} \mathrm{CD}_{138}{ }^{+}$subpopulations. When a total of $1 \times 10^{5}$ cells were plated, the number of colonies obtained from $\mathrm{CD}_{20} \mathrm{C}^{-} \mathrm{CD} 138$ subpopulation was significantly higher than that of $\mathrm{CD}_{2} 0^{+} \mathrm{CD}_{138}{ }^{+}$and $\mathrm{CD}^{2} \mathrm{O}^{+} \mathrm{CD}_{138^{-}}$subpopulations. The number of colonies was counted on day 23 when a total of $1 \times 10^{5}$ cells were plated, and on day 35 when a total of $5 \times 10^{4}$ cells were plated. ${ }^{*} P<0.05$ when compared with CD20- ${ }^{-}$D $138^{-}$cells.

colony formation, anti-apoptotic and ROS-expelling activities were detected. ${ }^{9}$ To date, CICs have not been identified in any kinds of non-Hodgkin's lymphomas. Here, we 
a
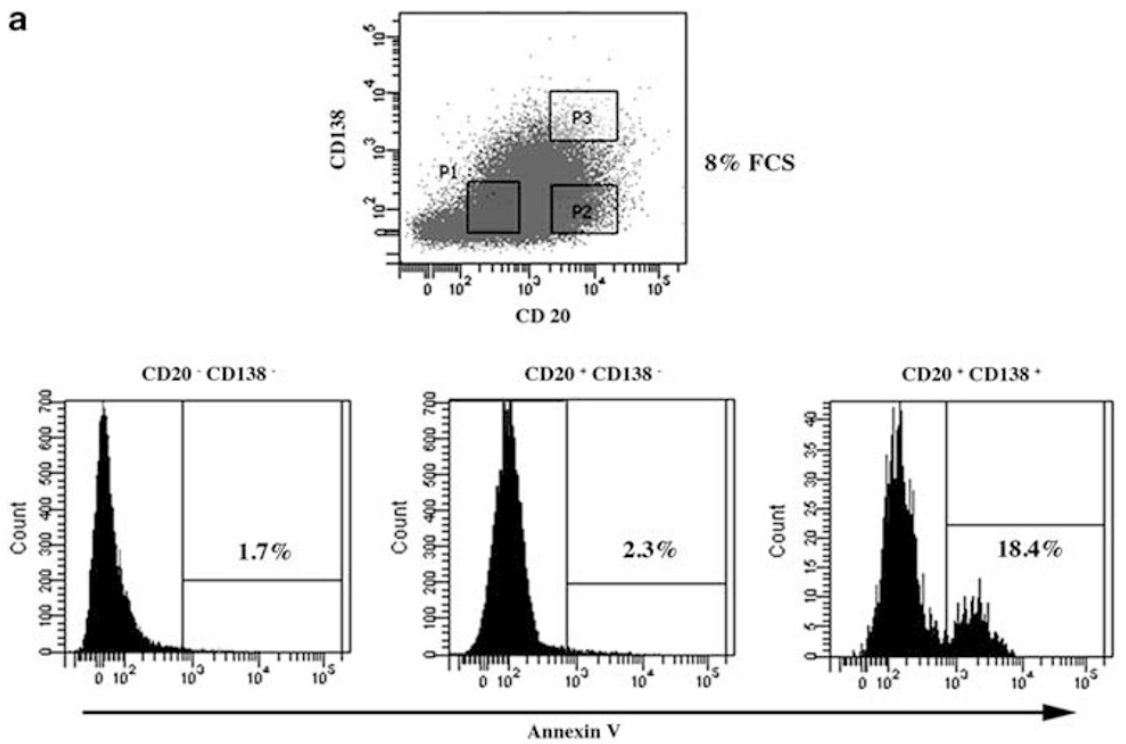

b
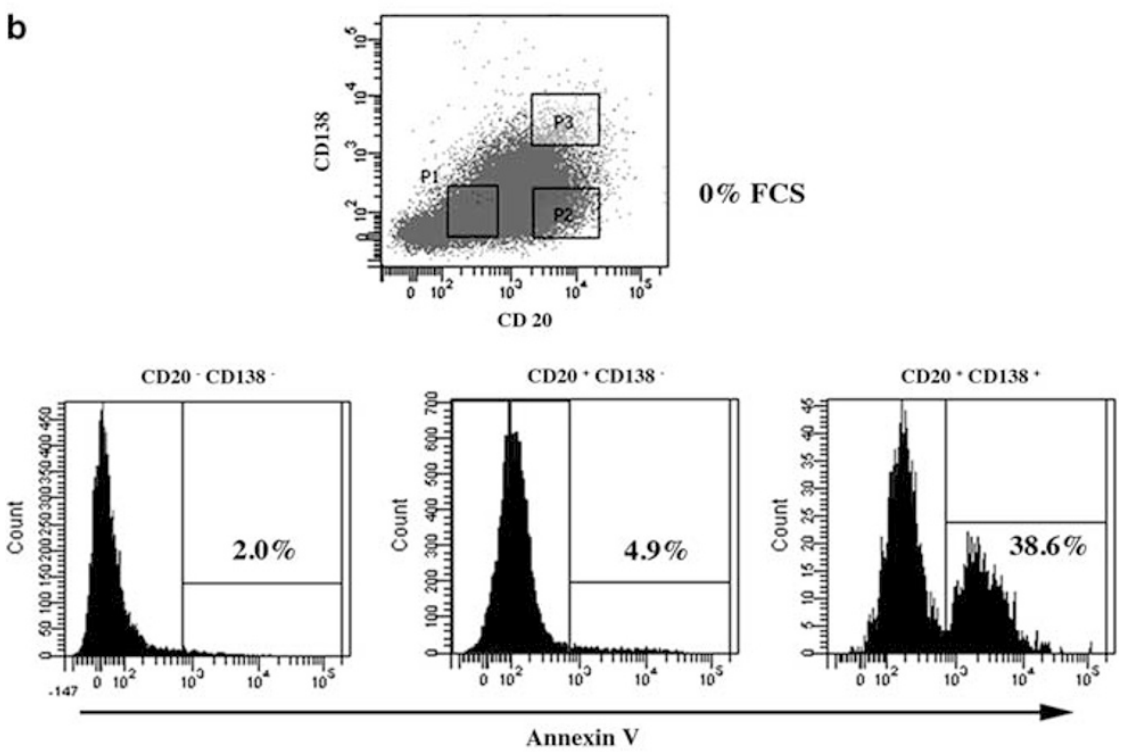

C

Proportion of Annexin V positive cells (\%)

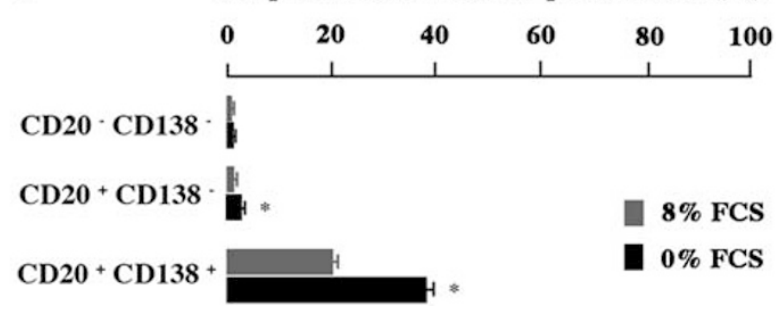

Figure 4 Resistance to apoptosis induced by serum starvation. MWCL-1 cells were cultured with (a) or without (b) FCS for $6 \mathrm{~h}$, and then the apoptotic cells in the three subpopulations were detected with Annexin V staining. (c) Proportion of Annexin V-positive cells was shown. ${ }^{*} P<0.05$ when compared with the presence of FCS.

investigated a candidate of CICs of WM using MWCL-1. WM tumor cells consist of small B lymphocytes, plasma cells, and lymphoplasmacytoid cells. In addition to the expression of the pan B-cell antigens such as CD20, WM tumor cells also coexpress the markers of mature plasma cells such as CD138.
In fact, MWCL-1 cells express both CD20 and CD138. When stained with anti-CD20 and anti-CD138 antibodies, most MWCL-1 cells were classified into three subpopulations: $\mathrm{CD} 20^{-} \mathrm{CD} 138^{-}, \mathrm{CD} 20^{+} \mathrm{CD} 138^{-}$, and $\mathrm{CD} 20^{+} \mathrm{CD} 138^{+}$. Then, these three subpopulations were sorted out and 
a
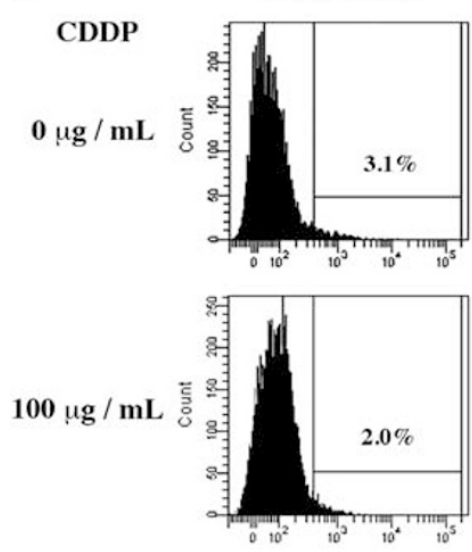

$\mathrm{CD} 20+\mathrm{CD} 138$
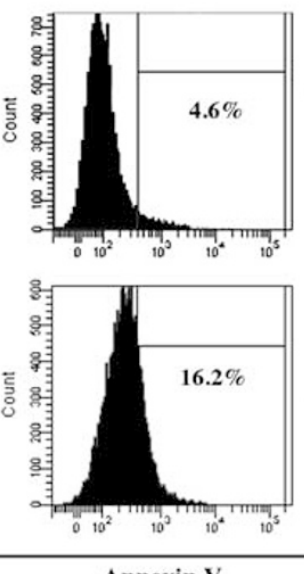

$\mathrm{CD}^{2}{ }^{+} \mathrm{CD} 138$ *
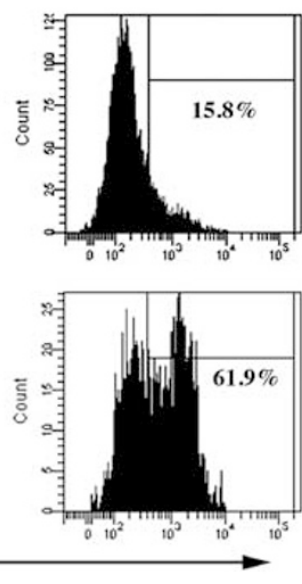

b Proportion of Annexin V positive cells (\%)

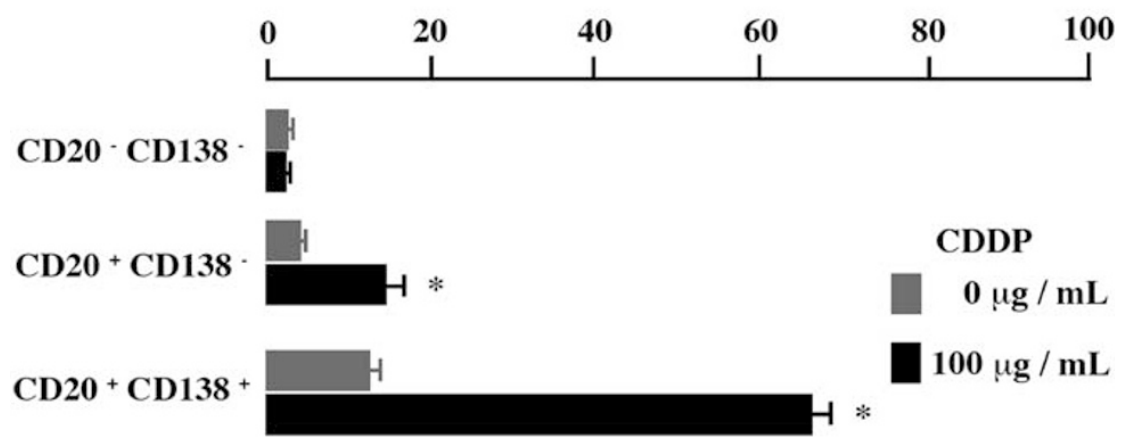

Figure 5 Resistance to apoptosis induced by anti-cancer drug. (a) MWCL-1 cells were cultured with or without $100 \mu \mathrm{g} / \mathrm{ml}$ CDDP for $36 \mathrm{~h}$, and the apoptotic cells in the three subpopulations were detected with Annexin V staining. (b) Proportion of Annexin V-positive cells was shown. ${ }^{*} P<0.05$ when compared with the absence of CDDP.

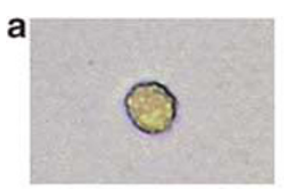

$\mathrm{CD} 20 \cdot \mathrm{CD} 138$

b

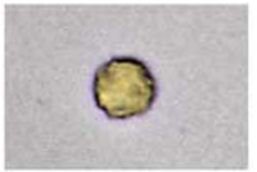

$\mathrm{CD} 20+\mathrm{CD} 138$

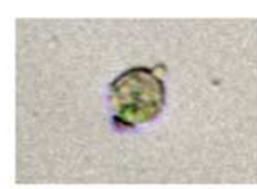

$\mathrm{CD} 20^{+}{ }^{\mathrm{CD}} 138$ +
Proportion of SA- $\beta-$ Gal positive cells $(\%)$

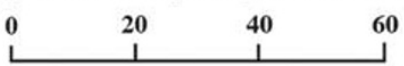

CD20 - CD138

$\mathrm{CD20}+\mathrm{CD} 138$.

$\mathrm{CD20}+\mathrm{CD}^{2} 38^{+}$

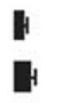

Figure 6 Cellular senescence of three subpopulations. (a) SA- $\beta$-Gal

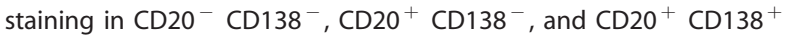
subpopulations revealed SA- $\beta$-Gal positive blue-stained cells were detected only in $\mathrm{CD}_{20}{ }^{+} \mathrm{CD} 138^{+}$subpopulation. (b) Proportion of SA- $\beta$ Gal positive cells. ${ }^{*} P<0.05$ when compared with $\mathrm{CD} 20^{-} \mathrm{CD} 138^{-}$ subpopulation.

examined. When cultured, $\mathrm{CD} 20^{-} \mathrm{CD} 138^{-}$cells yielded all three subpopulations, but $\mathrm{CD} 20^{+} \mathrm{CD} 138^{-}$and $\mathrm{CD} 20^{+}$ $\mathrm{CD}_{138^{+}}$cells did not yield $\mathrm{CD} 20^{-} \mathrm{CD} 138^{-}$cells. CICs are known to yield CICs and non-CICs, but non-CICs do not yield CICs. The result suggested that $\mathrm{CD} 20^{-} \mathrm{CD} 138^{-}$ subpopulation was the candidate of CICs in WM.

Recently, CICs have been reported to keep the concentration of ROS at a low level. ${ }^{9,10,12}$ When MWCL-1 cells pulsed with hydrogen peroxide were stained with ROS marker, CM$\mathrm{H}_{2}$ DCFDA, both ROS-high and ROS-low populations were detected. As compared with $\mathrm{CD}_{20}{ }^{+}$cells, $\mathrm{CD} 20^{-}$cells possessed a higher proportion of ROS-low population. As most $\mathrm{CD} 20^{-}$cells in MWCL-1 showed immunophenotype of $\mathrm{CD} 20^{-} \mathrm{CD}_{138^{-}}$, ROS-expelling activity of $\mathrm{CD} 20^{-} \mathrm{CD} 138^{-}$ cells appeared to be higher than that of $\mathrm{CD} 20^{+}$cells. This was consistent with the conclusion that $\mathrm{CD} 20^{-} \mathrm{CD} 138^{-}$cells were a candidate of CICs in WM. ROS-expelling activity is correlated with the nuclear accumulation of master regulatory transcription factor FoxO3a. ${ }^{19-21}$ In fact, the immunocytochemical analysis revealed that the nuclear localization of FoxO3a was preferentially detected in $\mathrm{CD}_{2} 0^{-}$cells. FoxO3a is degraded in the cytoplasm when activated by AKT. ${ }^{21-23} \mathrm{CD} 20$ is related to the stimulation of $\mathrm{B}$ cell receptor signaling, which activates $\mathrm{AKT}^{24,25}$ Owing to the lack of CD20, AKT might be unstimulated, resulting in the keep of FoxO3a expression and high ROS expelling activity in $\mathrm{CD} 20^{-} \mathrm{CD} 138^{-}$cells. 
a

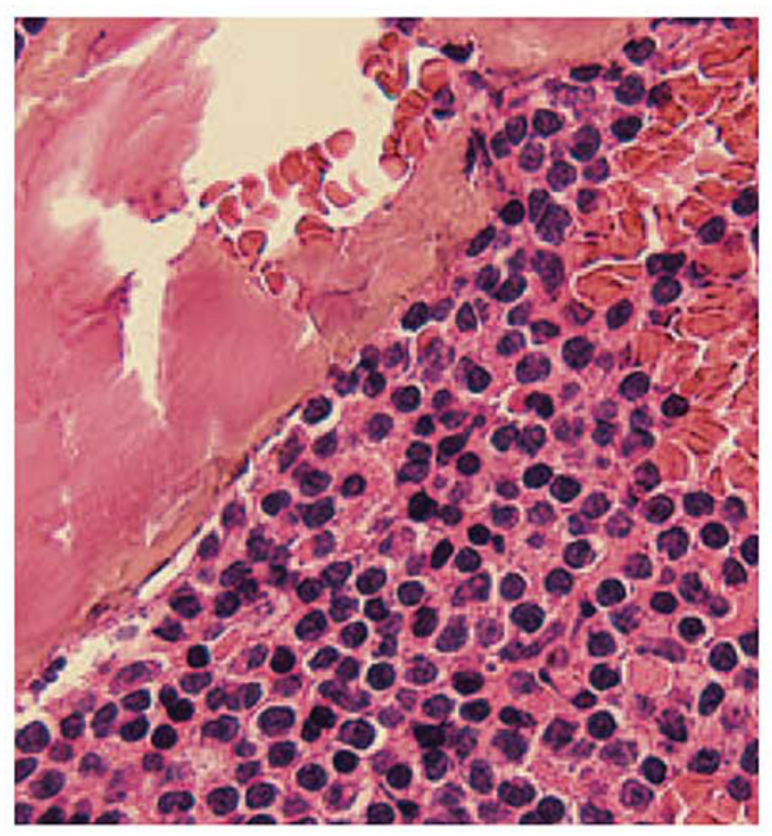

CD20

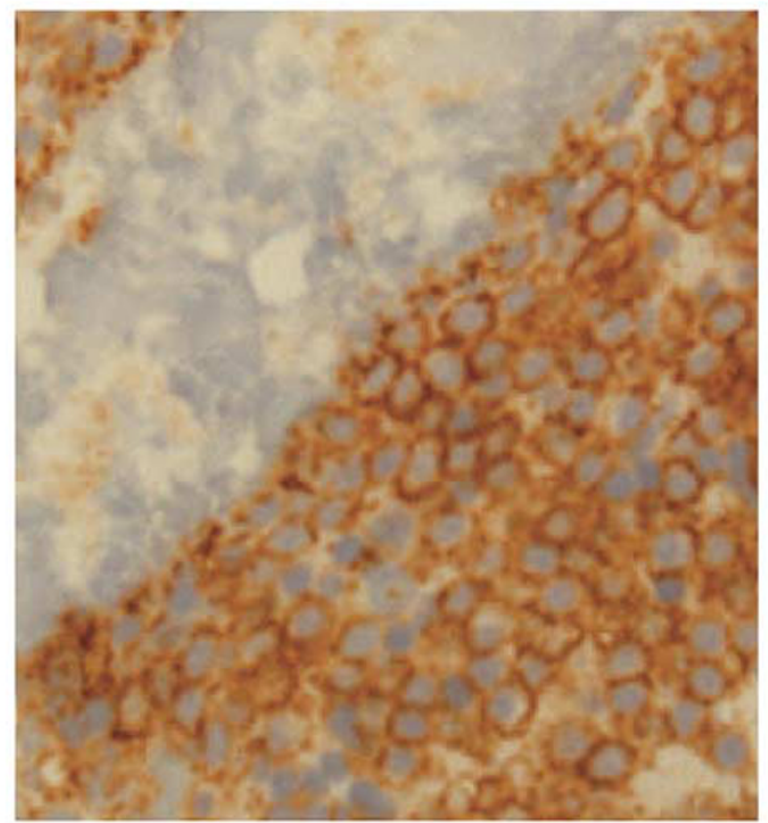

merge b

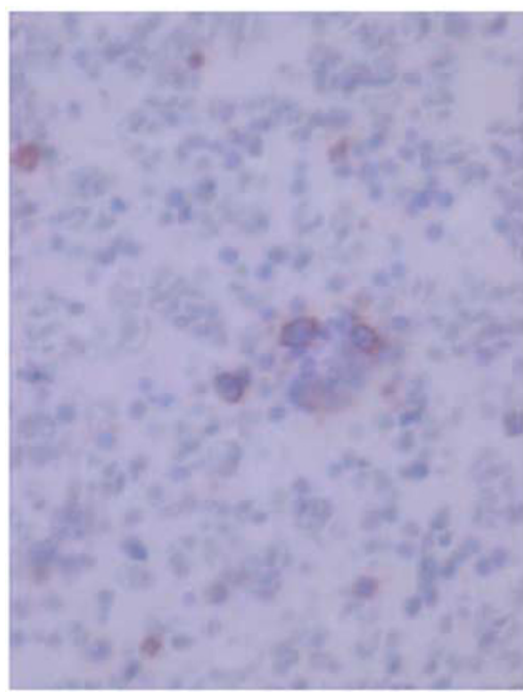

cleaved

caspase 3

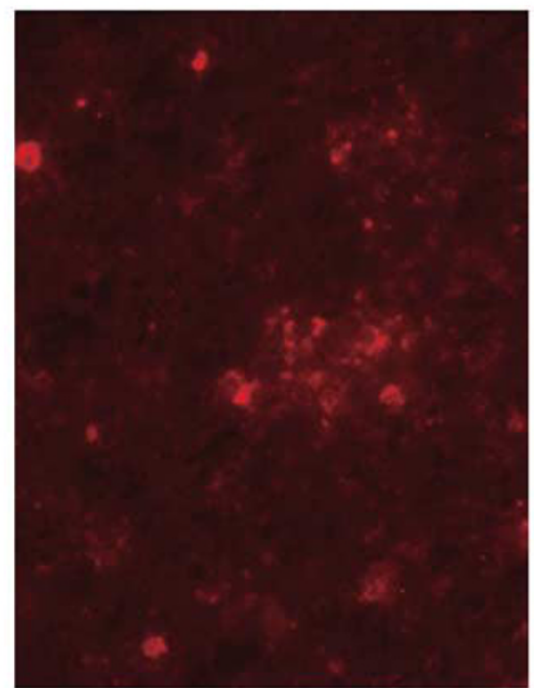

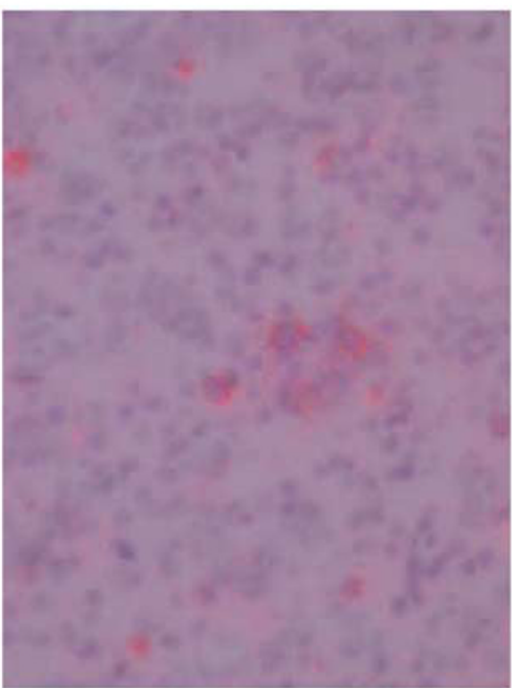

Figure 7 Immunohistochemistry in clinical samples of lymphoplasmacytic lymphoma. (a) Representative image of HE and CD20 staining in a serial section ( $\times 400$ ). Almost all tumor cells were CD20-positive. (b) Double staining of CD138 and cleaved-caspase 3. CD138-positive cells were shown in brown, and cleaved-caspase 3-positive cells in red. Merged image was also shown. Most CD138 ${ }^{+}$cells were stained with cleaved-caspase 3.

CICs possess high colony formation ability when cultured in semisolid condition..$^{9-11}$ In methylcellulose culture, the number of colony obtained from $\mathrm{CD} 20^{-} \mathrm{CD} 138^{-}$cells was the highest than that of $\mathrm{CD} 20^{+} \mathrm{CD} 138^{-}$and $\mathrm{CD} 20^{+}$ $\mathrm{CD}_{138^{+}}$cells. In addition, the escape from apoptosis is a prerequisite for CICs. ${ }^{26}$ Then, we further investigated the resistance of apoptosis induced by starvation and anti-cancer drug CDDP. As expected, the rank order of resistance to apoptosis was as follows: $\mathrm{CD} 20^{-} \mathrm{CD}_{138^{-}}>\mathrm{CD} 20^{+}$ $\mathrm{CD} 138^{-}>\mathrm{CD} 20^{+} \mathrm{CD} 138^{+}$. These results supported the current conclusion that $\mathrm{CD}_{2} 0^{-} \mathrm{CD}_{138^{-}}$cell was a candidate for CICs of WM.

In contrast to $\mathrm{CD} 20^{-} \mathrm{CD} 138^{-}$cells, $\mathrm{CD} 20^{+} \mathrm{CD} 138^{+}$ cells were vulnerable to apoptosis. Studies with clinical samples of LPL revealed that the apoptotic cells were mostly $\mathrm{CD} 20^{+} \mathrm{CD}_{138^{+}}$, which was consistent with the result obtained in MWCL- $1 . \mathrm{CD} 20^{+} \mathrm{CD} 138^{+}$cells showed the highest SA- $\beta$-Gal activity, a known characteristic of senescent cells. Therefore, the therapy driving $\mathrm{CD} 20^{-} \mathrm{CD} 138^{-}$cells to $\mathrm{CD} 20^{+} \mathrm{CD} 138^{+}$status will be helpful to cure LPL. 
As compared with the examined three populations, the number of $\mathrm{CD}_{20}{ }^{-} \mathrm{CD} 138^{+}$cells was extremely low. The senescent cells were observed in $\mathrm{CD} 20^{+} \mathrm{CD} 138^{+}$subpopulation, suggesting that $\mathrm{CD} 20^{+} \mathrm{CD} 138^{+}$may be in the most differentiated status. The differentiation process might start at $\mathrm{CD} 20^{-} \mathrm{CD} 138^{-}$cells, which appeared to change to $\mathrm{CD}_{20}{ }^{+} \mathrm{CD}_{138}{ }^{-}$and then to $\mathrm{CD} 20^{+} \mathrm{CD}_{138^{+}}$cells. Although the biological meaning of $\mathrm{CD} 20^{-} \mathrm{CD} 138^{+}$cells was obscure, the main stream of phenotype change did not appear to go through $\mathrm{CD} 20^{-} \mathrm{CD} 138^{+}$status. In the current study, $\mathrm{CD} 20^{+} \mathrm{CD} 138^{-}$and $\mathrm{CD} 20^{+} \mathrm{CD} 138^{+}$cells were interchangeable, suggesting that the process from $\mathrm{CD} 20^{+}$ $\mathrm{CD} 138^{+}$to $\mathrm{CD} 20^{+} \mathrm{CD} 138^{-}$might be dedifferentiation.

Immunohistochemically, most tumor cells were CD20positive in clinical samples of LPL, and $\mathrm{CD} 20^{-} \mathrm{CD} 138^{-}$ cells were hardly detected. Recently, it has been reported that the high proportion of CICs is correlated to poor prognosis in several tumors. ${ }^{27}$ To evaluate the prognosis of LPL, useful markers expressing in $\mathrm{CD} 20^{-} \mathrm{CD} 138^{-}$cells will be required.

Supplementary Information accompanies the paper on the Laboratory Investigation website (http://www.laboratoryinvestigation.org)

\section{ACKNOWLEDGMENTS}

The authors thank Professor Ansell SM, Mayo Foundation for Medical Education and Research, for providing MWCL-1, and Ms Sawamura T, Nihei $\mathrm{M}$, and Maeno E for technical assistance and support. This work was supported by grants from the Ministry of Education, Culture, Sports, Science and Technology, Japan (no. 23590425, no. 25860268, no. 25460435, and no. 25460436).

\section{DISCLOSURE/CONFLICT OF INTEREST}

The authors declare no conflict of interest.

1. Bonnet D, Dick JE. Human acute myeloid leukemia is organized as a hierarchy that originates from a primitive hematopoietic cell. Nat Med 1997;3:730-737.

2. Reya T, Morrison SJ, Clarke MF, et al. Stem cells, cancer, and cancer stem cells. Nature 2001;414:105-111.

3. Al-Hajj M, Wicha MS, Benito-Hernandez A, et al. Prospective identification of tumorigenic breast cancer cells. Proc Natl Acad Sci USA 2003;100:3983-3988.

4. Lessard J, Sauvageau G. Bmi-1 determined the proliferative capacity of normal and leukaemic stem cells. Nature 2003:423:255-260.

5. Kondo T, Setoguchi T, Taga T. Persistence of a small subppulation of cancer stem-like cells in the C6 glioma cell line. Proc Natl Acad Sci USA 2004;101:781-786.

6. Singh SK, Hawkins C, Clarke ID, et al. Identification of human brain tumour initiating cells. Nature 2004;432:396-401.

7. O'Brien CA, Pollett A, Gallinger S, et al. A human colon cancer cell capable of initiating tumor growth in immunodeficient mice. Nature 2007;445:106-110.
8. Ricci-Vitiani L, Lombardi DG, Pilozzi E, et al. Identification and expansion of human colon-cancer initiating cells. Nature 2007:445:111-115.

9. Ikeda J, Mamat S, Tian $\mathrm{T}$, et al. Tumorigenic potential of mononucleated small cells of Hodgkin lymphoma cell lines. Am J Pathol 2010;177:3081-3088.

10. Ikeda J, Mamat S, Tian T, et al. Reactive oxygen species and aldehyde dehydrogenase activity in Hodgkin lymphoma cells. Lab Invest 2012;92:606-614.

11. Hamburger AW, Salmon SE. Primary bioassay of human tumor stem cells. Science 1977;197:461-463.

12. Diehn M, Cho RW, Lobo NA, et al. Association of reactive oxygen species levels and radioresistance in cancer stem cells. Nature 2009;458:780-783.

13. Owen RG, Treon SP, Al-Katib A, et al. Clinicopathological definition of Waldenstrom's macroglobulinemia: consensus panel recommendations from the Second International Workshop on Waldenstrom's macroglobulinemia. Semin Oncol 2003;30:110-115.

14. Swerdlow SH, Berger F, Pileri SA, et al. Lymphoplasmacytic lymphoma. In: Swerdlow SH, Campo E, Harris NL, et al. (eds WHO Classification of Tumours of Haematopoietic and Lymphoid Tissues. 4th ed. (, Lyon, 2008) p194-195.

15. Barakat FH, Medeiros J, Wei EX, et al. Residual monotypic plasma cells in patients with Waldenstrom macroglobulinemia after therapy. Hematopathology 2011;135:365-373.

16. Konoplev S, Medeiros J, Bueso-Ramos $\mathrm{CE}$, et al. Immunophenotypic profile of lymphoplasmacytic lymphoma/Waldenstrom macroglobulinemia. Am J Clin Pathol 2005;124:414-420.

17. Morice WG, Chen D, Kurtin PJ, et al. Novel immunophenotypic features of marrow lymphoplasmacytic lymphoma and correlation with Waldenstrom's macroglobulinemia. Mod Pathol 2009;22: 807-816.

18. Hodge LS, Novak AJ, Grote DM, et al. Establishment and characterization of a novel Waldenstrom macroglobulinemia cell line, MWCL-1. Blood 2011;117:e190-e197.

19. Tothova Z, Kollipara R, Huntly BJ, et al. FoxOs are critical mediators of hematopoietic stem cell resistance to physiologic oxidative stress. Cell 2007;128:325-339.

20. Miyamoto K, Araki KY, Naka K, et al. FoxO3a is essential for maintenance of hematopoietic stem cell pool. Cell Stem Cell 2007;1:101-112.

21. Burgering BM. A brief introduction to FOXOlogy. Oncogene 2008;27:2258-2262.

22. Brunet $A$, Bonni $A$, Zigmond MJ, et al. Akt promotes cell survival by phosphorylating and inhibiting a Forkhead transcription factor. Cell 1999:96:857-868.

23. Brownawell AM, Kops GJ, Macara IG, et al. Inhibition of nuclear import by protein kinase $B$ (Akt) regulates the subcellular distribution and activity of the forkhead transcription factor AFX. Mol Cell Biol 2001:21:3534-3546.

24. Franke A, Niederfellner GJ, Klein C, et al. Antibodies against CD20 or B-cell receptor induce similar transcription patterns in human lymphoma cell lines. PLoS One 2011;6:e16596.

25. Limon JJ, Fruman DA. Akt and mTOR in B cell activation and differentiation. Front Immunol 2012;3:1-12.

26. Signore M, Ricci-Vitiani L, De Maria R. Targeting apoptosis pathways in cancer stem cells. Cancer Lett 2013;332:374-382.

27. Cheng L, Alexander R, Zhang $\mathrm{S}$, et al. The clinical and therapeutic implications of cancer stem cell biology. Expert Rev Anticancer Ther 2011;11:1131-1143. 